\title{
Thyroid nodules in acromegaly
}

\author{
Nódulos tiroideanos na acromegalia
}

Amelia Rogozinski', Alejandra Furioso', Patricia Glikman', Marcelo Junco', Rosa Laudi ${ }^{2}$, Adriana Reyes', Alicia Lowenstein'

' División Endocrinología, Hospital J. M. Ramos Mejía,

Buenos Aires, Argentina ${ }^{2}$ Anatomia Patológica, Hospital J. M. Ramos Mejía, Buenos Aires, Argentina

Correspondence to:

Amelia Rogozinski

División Endocrinología,

Hospital J. M. Ramos Mejía

Urquiza 609, 1221, CABA, Argentina

ameliasu2000@yahoo.com.ar

Received on Jan/19/2012

Accepted on Jun/19/2012

\begin{abstract}
Objective: We made a prospective study evaluating the prevalence of thyroid nodular disease in acromegalic patients. Subjects and methods: Thyroid ultrasound and ultrasound-guided fine needle aspiration biopsy were performed when nodules were detected. Nodules were characterized by cytology and histopathology. Results: We found high prevalence of nodular thyroid disorder, 23/34 (67\%) in acromegalic patients. High risk and malignant cytology were significantly higher in acromegalic patients than in our non-acromegalic population (25\% vs. $9 \%)$. Differentiated thyroid carcinoma was present in $11 \%$ of the acromegalic patients. Conclusions: We strongly recommend periodic thyroid evaluation by ultrasound in patients with acromegaly. Fine needle aspiration biopsy should be performed in nodules larger than $10 \mathrm{~mm}$, and in all suspicious nodules, regardless of the size. Arq Bras Endocrinol Metab. 2012;56(5):300-4
\end{abstract}

Keywords

Acromegaly; thyroid nodules; thyroid ultrasonography; fine needle aspiration biopsy; thyroid carcinoma

\section{RESUMO}

Objetivo: Realizamos um estudo prospectivo avaliando a prevalência de patologia nodular tireóidea em 34 pacientes acromegálicos. Sujeitos e métodos: Avaliamos os pacientes com ecografia tireóidea e punção biópsia com agulha fina quando se detectavam nódulos. Resultados: Encontramos uma alta prevalência de patologia nodular tireóidea 23/34 (67\%) em acromegálicos. A citologia tireóidea de alto risco e maligna foi significativamente mais elevada em pacientes acromegálicos que em uma população não acromegálica ( $25 \%$ vs. $9 \%$ ). 0 grupo acromegálico apresentou carcinoma diferenciado de tireoides em $11 \%$. Conclusões: Recomendamos fortemente a ecografia periódica tireóidea em pacientes acromegálicos. Uma punção biópsia aspirativa com agulha fina deve ser realizada em presença de nódulos tireóideos maiores que $10 \mathrm{~mm}$ e daqueles com critérios ecográficos suspeitos de malignidade, independentemente do tamanho deles. Arq Bras Endocrinol Metab. 2012;56(5):300-4

Descritores

Acromegalia; nódulos tireóideos; ecografia tireóidea; punção biópsia aspirativa tireóidea; carcinoma tireóideo

\section{INTRODUCTION}

A cromegaly is a chronic and multisystemic disease, with an estimated prevalence of 40-70 cases/million (1-2). Chronic GH hypersecretion is caused by benign pituitary adenoma in most of the cases (3).

It is established that untreated acromegaly is associated with reduced life expectancy. Several studies have demonstrated a 2-3 fold increase in mortality due to cardiovascular, respiratory, and metabolic disease. These patients may have a greater risk of developing neoplastic disease as a consequence of their high GH and IGF-I levels (4). The prevalence of this association is still controversial, as most studies have been uncontrolled (5). An increased incidence of colorectal, breast, prostate, and hematological malignancies (6) has also been described in acromegalic patients.

It is well known that benign thyroid lesions, such as diffuse goiter and especially multinodular goiter, occur frequently in acromegalic patients (7). Thyroid carcinoma is among the malignancies reported to be associated with acromegaly in epidemiological studies (8). The actual incidence of thyroid cancer in acromegalic patients and the impact of active acromegaly on the development of thyroid cancer is still unknown (5). 
Most of the reports are retrospective and do not have selection criteria.

We present a prospective study that evaluated thyroid nodules in 34 consecutive acromegalic patients.

\section{SUBJECTS AND METHODS}

We studied 34 consecutive acromegalic patients (12 men and 22 women), 25-80 years old. Acromegaly was diagnosed according to clinical data, OGTT-GH test and IGF-I serum levels.

Acromegalic patients were at different disease status at the first appointment. Some patients were enrolled without any treatment $(\mathrm{n}=11)$, and others with previous treatments, such as surgery, radiotherapy, or somatostatin analogs $(n=23)$. Despite of these treatments, 33 out of 34 patients had active disease.

Serum IGF-I was measured using an IRMA assay after acid-ethanol extraction (DSL, Webster, TX). IGF-I data were analyzed following logarithmically transformed IGF-I values. Data were converted into Standard Deviation Scores (SDS) using reference values, according to the following formula: $(\mathrm{x}$-average $\mathrm{x}) / \mathrm{SD}$, where $\mathrm{x}=\log$ IGF-I of the patient, average $\mathrm{x}=$ mean $\log$ IGF-I at the corresponding age and sex, and SD = standard deviation from the mean. Active disease was defined by clinical features and IGF-I serum concentrations over 2 SDS. Duration of the disease was estimated taking into account medical history, clinical, and laboratory data.

GH, TSH, Free T4 (FT4), and anti-thyroperoxidase antibodies (TPOAb.) were measured using an immunochemiluminescent automated assay (IMMULI$\mathrm{TE}$, Siemens). Reference ranges in our laboratory were (0.5-4.0) $\mathrm{\mu UI} / \mathrm{mL}$ for TSH, (0.9-2.0) ng/dL for FT4, and $<20 \mathrm{UI} / \mathrm{mL}$ for ATPO.

All patients were evaluated by thyroid ultrasound scan Philips Envisor HD Ultrasound Machine (US) for the presence of diffuse, uninodular, and multinodular goiter (9). Ultrasound-guided fine needle aspiration biopsies (FNAB) of the thyroid were performed in nodules larger than $1 \mathrm{~cm}$ in diameter. When malignancy was suspected by known US criteria (hypoechogenicity compared to the normal thyroid parenchyma, increased intranodular vascularity, irregular infiltrative margins, presence of microcalcifications, absent halo, and a shape taller than the width measured in the transverse dimension), FNAB was performed, no matter the size of the nodule. Cytological results were classified in one of four categories, according to the Bethesda system
(10), unsatisfactory (Bethesda I), benign (Bethesda II), high risk (Bethesda III, IV and V), and malignant (Bethesda VI). Patients with suspicious (Bethesda V) and malignant (Bethesda VI) cytology were sent to surgery.

As a control group, we considered cytology results of 8,532 FNAB performed in our Thyroid Unit between October 1994 and February 2010. These patients were clinically evaluated in order to exclude pituitary disease. This group consisted of $92 \%$ females and the distribution of age was: $0.7 \%$ under 20 years old, $13.5 \%$, between 20 and 40 years old, $47.9 \%$ between 40 and 60 years old, and $37.8 \%$ over 60 years old (range: 14-87 years old).

This study was submitted and approved by the Ethics Committee of our hospital.

Statistics: Unpaired t test, Multiple Regression test, and Fisher's Exact test were performed using GraphPad Instat software (version 3.06).

\section{RESULTS}

\section{Clinical data of the patients}

We studied 34 consecutive patients (Table 1), 22 women and 12 men, median age of 55 years old (range 25-80). Patients with and without goiter had similar median age (Unpaired t test).

Active acromegaly was diagnosed in 33 patients, with IGF-I SDS median $=5.4$, range $=(2.1-10.1)$. In all active acromegalic patients, GH serum levels after

Table 1. Clinical data

\begin{tabular}{lcccc}
\hline & $\begin{array}{c}\text { Patients } \\
\text { without } \\
\text { goiter }\end{array}$ & \multicolumn{3}{c}{ Patients with goiter } \\
\cline { 3 - 5 } & 5 & 6 & 11 & 12 \\
\hline No. of patients & & & & \\
Age (years) & & & & \\
$\quad$ Median & & 47 & 58 & 58 \\
$\quad$ Range & $(25-60)$ & $(38-70)$ & $(26-80)$ & $(31-73)$ \\
Gender (n) & & & & \\
$\quad$ Female & 2 & 2 & 8 & 10 \\
$\quad$ Male & 3 & 4 & 3 & 2 \\
Disease activity & $5 / 5$ & $6 / 6$ & $10 / 11$ & $12 / 12$ \\
IGF-I (SDS) & & & & \\
Median & 6.6 & 5.1 & 5.3 & 5.3 \\
Range & $(5.8-10.1)$ & $(2.5-6.7)$ & $(1.4-9.1)$ & $(2.5-8.6)$ \\
Evolution (years) & & & & 12 \\
Median & 5 & 6 & 11 & $(1-20)$ \\
Range & $(1-14)$ & $(3-25)$ & $(3-40)$ & \\
\hline
\end{tabular}


OGTT were higher than $1 \mathrm{ng} / \mathrm{mL}$. Goiter was present in $85 \%(29 / 34)$ of the acromegalic patients: $69 \%$ were women, $50 \%$ of them with polynodular goiter, and $40 \%$ with uninodular goiter. Diffuse goiter was predominantly seen in men $(44.4 \%)$. Higher incidence of thyroid nodules was seen in females $(18 / 22) v s$. men $(5 / 12)$ (Fisher's Exact test, $\mathrm{p}=0.0256$ ).

Except for one patient with history of Graves' disease, none had previous thyroid disease.

Euthyroidism was present in $32 / 34$ acromegalic patients; $2 / 34$ patients had secondary hypothyroidism. One patient who was euthyroid at the first appointment, developed hyperthyroidism associated to thyrotropinoma 6 months later $(\mathrm{TSH}=1.77 \mu \mathrm{UI} / \mathrm{mL}$ and FT4 $=2.69 \mathrm{ng} / \mathrm{dL}$ ). There were no significant differences in TSH or FT4 levels between patients with or without goiter (Unpaired t test). Median and (range) were: $1.22(0.26-3.40) v s .1 .10(1.03-2.60) \mu \mathrm{UI} / \mathrm{mL}$ for TSH, and 1.27 (0.74-1.60) vs. 1.20 (1.10-1.70) ng/dL for FT4, respectively. Only $3 / 34$ patients had positive TPOAb levels.

The presence of goiter in our acromegalic population did not show any association with their age, gender, or disease history (Multiple Regression test). However, patients with nodular goiter had a trend toward a longer history of acromegaly.

\section{Thyroid nodular ultrasound scan}

Thyroid nodules were detected by US in $23 / 34$ (67\%) patients. Nodules were mostly hypoechoic (17/23), and $18 / 23$ were larger than $10 \mathrm{~mm}$ in diameter. US characteristics in multinodular goiter were based only on the largest nodule (Table 2).

Table 2. US of nodular goiter

\begin{tabular}{cccccccc}
\hline \multicolumn{2}{c}{ Nodules } & \multicolumn{3}{c}{ US characteristics } & \multicolumn{3}{c}{ Size (cm) } \\
\hline UNG & MNG & HYPOECHO & ISOECHO & ANECHO & $<1$ & $1-2$ & $>2$ \\
11 & 12 & 17 & 1 & 5 & 5 & 12 & 6 \\
\hline
\end{tabular}

UNG: uninodular goiter; MNG: multinodular goiter; HYPOECHO: hypoechoic; ISOECHO: isoechoic; ANECHO: anechoic.

\section{Thyroid nodular cytology}

In our Thyroid Unit, with a large experience in 8,532 FNAB, the distribution of thyroid cytology was: $2 \%$ malignancy (Bethesda VI), 7\% high risk (Bethesda III, IV, V), 63\% benign (Bethesda II), 3\% cysts, and 15\% unsatisfactory (Bethesda I).

In this study, FNAB was performed in 18 patients (Table 3). Benign cytology (Bethesda II) was found in
13 patients. Two nodules showed high risk cytology: the first with follicular proliferation (Bethesda III) with a 7-mm diameter nodule, and the other one suspicious for malignancy (Bethesda $\mathrm{V}$ ) with a $12-\mathrm{mm}$ diameter nodule. Malignant cytology (Bethesda VI) was found in two nodules: one of them of $14 \mathrm{~mm}$, and the other with $8 \mathrm{~mm}$ in diameter. Only one sample was unsatisfactory (Bethesda I).

In summary, high risk and malignant cytology occurred in $22.2 \%$ cases of acromegaly. However, in our previously studied non-acromegalic population of $8,532 \mathrm{FNAB}$, this result was equal to $9.0 \%$

FNAB of a cervical node was also performed in a female patient who did not present nodular goiter. Metastatic follicular carcinoma was diagnosed by cytology.

Table 3. FNAB, thyroid nodular cytology

\begin{tabular}{lccccc}
\hline Cytology & $\begin{array}{c}\text { Non- } \\
\text { diagnostic }\end{array}$ & Benign & $\begin{array}{c}\text { Follicular } \\
\text { proliferation }\end{array}$ & $\begin{array}{c}\text { Suspicious } \\
\text { for } \\
\text { malignacy }\end{array}$ & Malignant \\
\hline $\mathrm{n}=18$ & 1 & 13 & 1 & 1 & 2 \\
\hline
\end{tabular}

\section{Surgery}

Five patients underwent thyroid surgery. Histology results confirmed one case of colloid goiter, three of papillary carcinoma, and one of follicular carcinoma. We diagnosed four differentiated thyroid carcinomas in 34 consecutive acromegalic patients. All these patients were females.

Follicular carcinoma was diagnosed by FNAB in a cervical adenopathy, without the finding of the primitive thyroid tumor at surgery. It should be emphasized that detection of the primary neoplasm may require extremely careful microscopic study, with embedding of the entire thyroid gland, and cutting of blocks at various levels (11).

The remaining cases had neither lymphadenopathy nor extra thyroidal extensions.

Three of the four patients diagnosed with differentiated thyroid carcinoma were free of disease two years after the surgery. The fourth patient recently underwent surgery. In the first control, persistence of the disease was not observed.

\section{DISCUSSION}

Acromegaly is a rare disease caused by excess GH, which in most cases is due to a pituitary adenoma. Acromegaly is accompanied by organomegaly, metabolic deterioration, 
comorbidities, and increased mortality (4). Neoplasms are often found, but their incidence is controversial (6).

The association between acromegaly and goiter has long been recognized. However, the evaluation of thyroid disorders in the presence of GH and IGF-I excess has yielded conflicting results, since the prevalence of thyroid disease in acromegaly ranged from $25 \%$ to $92 \%$ in different series (7-14). These discrepancies may be partially explained by differences in how goiter was diagnosed: palpation, imaging studies, such as US, or evaluation of iodine intake in the area.

In our study, we performed US in all of the acromegalic patients to evaluate thyroid size and nodular pathology in a known iodine-sufficient area (15).

Gasperi and cols. (7) reported, in an Italian multi-center study of 258 acromegalic patients, that $78 \%$ had thyroid disease. In the control group (non-functioning adenomas or prolactinomas), they found that $27 \%$ of the patients had thyroid disease. The prevalence was higher in acromegalic patients with nodular, diffuse nontoxic goiter, and toxic nodular goiter.

Chronic elevation of GH and IGF-I levels could be responsible for benign nodules and tumors in this disease. IGF-I acts by means of two mechanisms: increasing proliferation and reducing apoptosis. It was demonstrated that IGF-I increases proliferation of porcine thyroid cells and FRTL-5 rat thyroid cells, and potentiates TSH-mediated thyroid cell proliferation (4-16). In physiological conditions, thyroid follicular cells express IGF-I receptors. Local IGF-I is suggested by the detection of its production in follicular and papillary cell lines $(17,18)$. In surgical thyroid specimens, tumoral immunoreactive IGF-I levels were greater than in normal tissue $(4,19)$. Thus, bioactivity of IGF-I tissue in vivo does not result only from IGF-I and IGFBP3 serum levels, but also from its local production, which adds to an autocrine-paracrine effect (12).

In our study, serum IGF-I levels were not significantly associated with the presence of goiter. We performed this study in a prospective and consecutive format in 34 acromegalic patients, focusing on the thyroid nodular disease. We indicated thyroid US at the first appointment in all 34 consecutive acromegalic patients. We found goiter in $85 \%$ of the patients, and thyroid nodules in $67 \%$ of them, similar to literature findings (7).

Patients with and without goiter had similar median age. Higher incidence of thyroid nodules was seen in females $(p=0.0256)$. The chance of developing thyroid nodules increased with the duration of the disease
(14). Although we found a trend toward a longer history of acromegaly in our patients with nodular goiter, this association was not statistically significant.

Acromegaly treatment inhibits peripheral thyroid hormone deiodination, decreasing T3 and increasing rT3 (20). It is tempting to speculate that the control of the disease could determine changes in the evolution of the thyroid nodules. Most of our patients with nodular goiter had active acromegaly when they were enrolled. Thus, we cannot know if changes in the activity of the disease are responsible for differences in the evolution of thyroid disease.

We studied the evolution of thyroid nodules of 15 acromegalic patients whose IGF-I serum levels were decreased by different treatments. We compared these results with the evolution of nodular goiter in 45 euthyroid non-acromegalic patients after 12 months of routine follow-up by US. We did not find any significant difference between both groups (data not shown).

Most studies focusing on cancer incidence and/or prevalence do not provide conclusive evidence of increased cancer risk (21), but most of them were retrospective and uncontrolled (6). We found an increased incidence of thyroid cancer in our acromegalic patients, which was not observed in previous studies. The prospective and controlled design of our study could be the explanation of this difference.

Since acromegaly is a rare disease, it is difficult to have enough patients for statistical analysis at a single center. In this study we found that high risk and malignant cytology was $22.2 \%$ in acromegalic patients, whereas it was $9 \%$ in our previously studied non-acromegalic patients.

In the report by Gasperi and cols. (7), FNAB of thyroid nodules was performed in 62 acromegalic patients. Seven nodules were suspicious and patients were submitted to thyroid surgery, which found papillary thyroid carcinoma in three of them.

We diagnosed three papillary carcinomas and one follicular carcinoma in this study. The prevalence of thyroid carcinoma was $11 \%$ in our acromegalic patients.

The presence of men in our acromegalic group was different from our control group (35.3 vs. 8\%). Male gender is considered a risk factor for thyroid carcinoma. However, in our population of acromegalic patients, all carcinomas were found in females.

Gasperi and cols. (7) did not find differences in the incidence of thyroid carcinoma between acromegalic and patients with other pituitary adenomas (1.2 vs. $0.3 \%$ ). 
Baris and cols. (22) reported a standardized incidence ratio of 3.7 (95\% CI 1.8-10.9) for thyroid carcinoma in one of the largest analyses of 1,634 acromegalic patients. Kurimoto and cols. (23) found thyroid carcinoma in $4 / 83$ patients (4.8\%). Gullu and cols. (24) described thyroid cancer as the most common malignancy associated with acromegaly: the incidence rate of thyroid cancer was $5 \%$ for all patients, and $8 \%$ in patients who had a nodule in the thyroid gland. Balkany and Cushing (25) reported that thyroid tumors are predominantly papillary and occasionally aggressive, as confirmed by the rare occurrence of multifocal tumors and by low mortality rates $(1,26)$.

In our experience, three out of four patients were monitored for more than 2 years after thyroid surgery. They were free from the disease. The fourth one underwent recent surgery, and up to now has not shown any evidence of persistent disease.

We are aware that our study has evaluated a limited number of acromegalic patients $(\mathrm{n}=34)$. This could have distorted our statistical analysis and could be the reason of the lack of association between age, gender, or disease history with the prevalence of thyroid nodular disease. However, we considered it was important to communicate that, in this prospective study of 34 consecutive acromegalic patients, we found:

- high prevalence of nodular thyroid pathology (67\%);

- malignant and high risk cytology higher than in our previously studied population of non-acromegalic patients ( $25 \%$ vs. $9 \%)$.

We strongly recommend periodic ultrasound evaluation of the thyroid gland in patients with acromegaly, based on the high incidence of differentiated thyroid carcinoma found in our group. Fine needle aspiration biopsy should be performed according to current criteria (27) in nodules larger than $10 \mathrm{~mm}$, and in all suspicious nodules, regardless of the size.

Disclosure: no potential conflict of interest relevant to this article was reported.

\section{REFERENCES}

1. Nabarro JDN. Acromegaly. Clin Endocrinol (Oxf). 1987;26:481-512.

2. Vasilev V, Daly A, Zacharieva S, Beckers A. Management of acromegaly. F1000 Med Rep. 2010;2:54.

3. Melmed S. Acromegaly. N Engl J Med. 1990;322:966-77.

4. Colao A, Ferone D, Marzullo P, Lombardi G. Systemic complications of acromegaly: epidemiology, pathogenesis, and management. Endocr Rev. 2004;25(1):102-52.

5. Siegel G, Tomer Y. Is there an association between acromegaly and thyroid carcinoma? A critical review of the literature. Endocr Res. 2005;31(1):51-8.
6. Loeper S, Ezzat S. Acromegaly: re-thinking the cancer risk. Rev Endocr Metab Disord. 2008;9(1):41-58.

7. Gasperi M, Martino E, Manetti L, Arosio M, Porretti S, Faglia G, et al. Acromegaly Study Group of the Italian Society of Endocrinology. Prevalence of thyroid diseases in patients with acromegaly: results of an Italian multi-center study. J Endocrinol Invest. 2002;25(3):240-5.

8. Orme SM, McNally RJ, Cartwright RA, Belchetz PE. Mortality and cancer incidence in acromegaly: a retrospective cohort study. United Kingdom Acromegaly Study Group. J Clin Endocrinol Metab. 1998;83(8):2730-4.

9. Middleton WD, Kurtz $A B$, Hertzberg BS. Ecografía. Madrid: Marban, 2005.

10. Cibas ES, Ali SZ. The Bethesda System for Reporting Thyroid Cytopathology. Thyroid. 2009;19:1159-65.

11. Klinck GH, Winship T. Occult sclerosing carcinoma of the thyroid. Cancer. 1955;8(4):701-6.

12. Ayuk J, Sheppard MC. Does acromegaly enhance mortality? Rev Endocr Metab Disord. 2008;9(1):33-9. Review

13. Kasagi K, Shimatsu A, Miyamoto S, Misaki T, Sakahara H, Konishi J. Goiter associated with acromegaly: sonographic and scintigraphic findings of the thyroid gland. Thyroid. 1999;9(8):791-6.

14. Cheung NW, Boyages SC. The thyroid gland in acromegaly: an ultrasonographic study. Clin Endocrinol (Oxf). 1997;46(5):545-9.

15. Gruñeiro-Papendieck L, Chiesa A, Mendez V, Bengolea S, Prieto L. NeonatalTSH levels as an index of iodine sufficiency: differences related to time of screening sampling and methodology. Horm Res. 2004;62(6):272-6.

16. Tramontano D, Cushing GW, Moses AC, Ingbar SH. Insulin-like growth factor-I stimulates the growth of rat thyroid cells in culture and synergizes the stimulation of DNA synthesis induced by TSH and Graves'-lgG. Endocrinology. 1986;119:940-2.

17. Tode B, Serio M, Rotella CM, Galli G, Franceschelli F, Tanini A, et al. Insulin-like growth factor-l: autocrine secretion by human thyroid follicular cells in primary culture. J Clin Endocrinol Metab. 1989;69:639-47.

18. Onoda N, Ohmura E, Tsushima T, Ohba Y, Emoto N, Isozaki O, et al. Autocrine role of insulin-like growth factor (IGF)-I in a human thyroid cancer cell line. Eur J Cancer. 1992;28A:1904-9.

19. Minuto F, Barreca A, Del Monte P, Cariola G, Torre GC, Giordano G. Immunoreactive insulin-like growth factor I (IGF-I) and IGF-I-binding protein content in human thyroid tissue. J Clin Endocrinol Metab. 1989;68:621-6.

20. Feldt-Rasmussen U. Interactions between growth hormone and the thyroid gland with special reference to biochemical diagnosis. Curr Med Chem. 2007;14(26):2783-8. Review

21. Melmed S. Acromegaly and cancer: not a problem? J Clin Endocrinol Metab. 2001;86(7):2929-34.

22. Baris D, Gridley G, Ron E, Weiderpass E, Mellemkjaer L, Ekbom A, et al. Acromegaly and cancer risk: a cohort study in Sweden and Denmark. Cancer Causes Control. 2002;13:395-400.

23. Kurimoto M, Fukuda I, Hizuka N, Takano K. The prevalence of benign and malignant tumors in patients with acromegaly at a single institute. Endocr J. 2008;55(1):67-71.

24. Gullu BE, Celik O, Gazioglu N, Kadioglu P. Thyroid cancer is the most common cancer associated with acromegaly. Pituitary. 2010;13(3):242-8.

25. Balkany C, Cushing GW. An association between acromegaly and thyroid carcinoma. Thyroid. 1995;5:47-50.

26. Barzilay J, Heatley GJ, Cushing GW. Benign and malignant tumors in patients with acromegaly. Arch Intern Med. 1991;151:1629-32.

27. Revised American Thyroid Association management guidelines for patients with thyroid nodules and differentiated thyroid cancer. American Thyroid Association (ATA) Guidelines Taskforce on Thyroid Nodules and Differentiated Thyroid Cancer, Cooper DS, Doherty GM, Haugen BR, Kloos RT, Lee SL, Mandel SJ, et al. Thyroid. 2009;19(11):1167-214. 